\title{
Altruism, gift giving and reciprocity in organ donation: A review of cultural perspectives
} and challenges of the concepts

\begin{abstract}
Living and deceased organ donation are couched in altruism and gift discourse and this article reviews explores cultural views toward these concepts. Altruism and egoism theories and gift and reciprocity theories are outlined from a social exchange theory perspective to highlight the key differences between altruism and the gift and the wider implications of reciprocation. The notion of altruism as a selfless act without expectation or want for repayment juxtaposed with the Maussian gift where there are the obligations to give, receive and reciprocate. Lay perspectives of altruism and the gift in organ donation are outlined and illustrate that there are differences in motivations to donate in different programmes of living donation and for families who decide to donate their relative's organs. These motivations reflect cultural views of altruism and the gift and perceptions of the body and death.
\end{abstract}




\section{Altruism, gift giving and reciprocity in organ donation: A review of cultural perspectives and challenges of the concepts}

\section{Introduction}

Across the Western world, there is a huge shortage of transplantable organs and to engage the public with organ donation, gift and altruism rhetoric has underpinned policy and campaigns. The interpretation of the concept of 'gift' and 'altruism' are couched in cultural and social norms and this article reviews how these notions are perceived across cultures in the context of living and deceased organ donation.

\section{Altruism, Gift and Reciprocity Theories}

This section will provide an account of altruism, gift and reciprocity theories, drawing upon social exchange theories.

\subsection{Altruism and Egoism}

Altruism and egoism theories have been widely debated. The philosopher Comte [1] purported altruism to be an ethical duty where individuals have the obligation to help others and not act for selfish gain. From an economic perspective, altruistic decisions are based on a cost-benefit analysis, assumed to be rational decisions made by utilitarian agents who seek justice and fairness in any exchange [2-4]. Social psychologists disagree with acts to help others to be a rational decision and suggest that altruism is motivated by the improvement of the positive welfare of others [5], either on a collective level to help society 
('collectivism') or through norms or rules ('principlism') [6]. Batson [6], a social psychologist believed that altruism was largely driven by empathy.

Socio-biologists suggested altruism is a human trait that is instinctive, driven by 'reciprocal altruism' [7] to protect the species [8-10]. Since humans are no longer in the food chain, this primal and instinctive level of protecting the species could have limited application.

Alternatively, humans may need to be taught to behave in altruistic ways to exercise moral reasoning in childhood by family members and school [11-13]. Simmons [14] cited Etzioni's [15] paradigm that suggested people are 'normative-affective beings' ( $p .13)$ where decisions are determined by conformity to norms and emotions as opposed to a rational choice. However, Simmons argues that norms maybe coercive as 'Society has developed norms to better insure help for the helpless...the satisfaction of the need for help does not depend solely on individual processes' (1991, p.13).

Challenges to pure altruism are the free-rider problem and bystander effect [16], both phenomenon assume individuals benefit from the acts of altruistic others that in turn reduces the likelihood of helping. Relying on others to help may reduce altruistic behaviour but doing something for another person has been found to be driven by self-interest in a number of studies [17-19] meaning that pure altruism could not exist. Philosophers Rand [20], Nietzsche [21] and Comte [1] argued 'the greatest problem of life [was achieving] the ascendancy of altruism over egoism' [1].

Overall, the altruism and egoism debate contribute toward the understanding behind the motivation to help others. The social psychological understanding of altruism is synonymous with organ donation as the focus is on the person in need whose life could be saved or improved by an organ, but it is simplistic and idealistic as decision making is complex and 
multi-faceted. The next section will come away from altruism and egoism and discuss exchange and reciprocity, both linked to gift exchange theory. The gift has been associated with organ donation and gift exchange theory has been used to analyse this relationship but before these are examined, social exchange theories and reciprocity will be explored.

\subsection{Social Exchange Theories}

To understand gift exchange theory and reciprocity, a brief overview of social exchange theories will be given to demonstrate its background. Exchange theories exist on two levels; on a micro level where individuals are concerned with exchanging resources with other individuals and on a macro level where exchanges occur between groups and within social systems where there is the belief that contributing toward the social system is rewarded with benefits.

Exchange theories have been developed by a wide range of scholars since the 1950s, for example:

- Blau [22], Emerson [23] and Friedman [24] argued an object in an exchange has a value given with economic motives to try to maximise profit from the exchange.

- Levi-Strauss [25] argued that 'goods are not only economic commodities but vehicles and instruments for realities of another order: influence, power, sympathy, status, emotion' (p.76).

- Simmel [26] purported exchanges were the basis of social relations.

Social exchange scholars agree exchanges between individuals or within social structures can have implications for defining the item's value, social relations within social structures, intention behind entering the exchange and the benefits gained from the exchange itself. 


\subsection{Reciprocity Theories}

Exchange theories may explain the intention to enter an exchange but do not describe the nature of the benefits or forms of reciprocity that may be gained from being in an exchange relationship. Reciprocity has been argued to be 'a vital principle of society' [27, p.12] that plays a significant role in social stability and is the foundation for social and ethical aspects of civilisation [28]. Simmel [29] purported social cohesion would not exist if it were not for reciprocity, although Malinowski [30] assumed obligations are owed as exchange had to balance out or penalties would be applied.

Gouldner [31] explored the norms of reciprocity through examining negative norms of reciprocity in unequal exchanges and positive norms of reciprocity underpinned by mutual gratification, cultural norms and moral norms but these can vary across cultural social systems. Both Gouldner and Malinowski imply social and cultural norms of reciprocity are present in exchanges.

The form of the exchange itself can impact on the expectation of the obligation to reciprocate or on the level of reciprocation. Anthropologists such as Levi-Strauss (1969), Malinowski [30] and Sahlins [32] differentiated between two typologies of exchange. They suggested there were direct or indirect exchange. In a direct exchange, there were two agents; agent $A$ and agent $B$ where $A$ will give to $B$ and vice versa, providing each other with the benefits of reciprocity. In generalised or indirect exchange, there are agents who give and over time will receive the benefits but not necessarily from the original agent. Indirect exchange produces stronger solidarity than direct exchange [33]. Takahashi [34] developed the concept of 'pure generalised exchange' where giving is unstructured and there is no set direction of reciprocity. 
Social exchange theories explain the implications of being part of an exchange relationship and reciprocity theory describes that direction of reciprocation and its importance. Gift theory describes the item in the exchange that invokes reciprocity.

\subsection{Gift Theories}

Gift exchange greatly differs from commodity exchange as within gift exchange, reciprocity is immediate and the item is alienable, meaning it is an impersonal and anonymous item. In gift exchanges, there can be a number of ways of interpreting the gift relationship and its place in capitalist, consumerist societies; below are examples of gift theories:

- Mauss [35] developed the gift exchange theory where there three obligations in the gift relationship; the obligation to give, the obligation to receive and the obligation to reciprocate where the item contained the 'spirit' of the giver.

- Gregory [36], Weiner [37] and Deguchi [38] focussed on the notion of inalienability in gift relationships, a notion coined by Mauss that describes items, which belong to society as a whole, holds high value. Godelier [39] in 'The Enigma of the Gift' expands on this and suggests society should be "keeping-for-giving and giving-forkeeping' as opposed to 'keeping-while-giving'.

- Hyde [40] examined gift economies in the modern world and suggested gifts are socially motivated and within gift economies honour, status and esteem replace monetary remuneration in the transaction.

- Bourdieu [41] stressed power or 'symbolic capital' in gift exchanges. 
Gift relationships between people or groups are influenced by the item that is given as a gift, the status of the gift giver, the circumstances at which the gift is given, how the gift is given and who the recipient of the gift is.

Altruism theories argued the motivation to help others is to increase the welfare of others and no reciprocity is expected but in the context of organ donation, families are entering a unique form of gift exchange with its own set social and cultural norms. The next section discusses the theoretical perspectives of altruism and gift exchange in organ donation.

\section{Altruism, gift theory and reciprocity in living and deceased organ donation}

There are several forms of living organ donation: directed altruistic donation to a relative and non-directed altruistic donation in paired and pooled donation: 2-way exchange; 3-way exchange; list-exchange and non-directed altruistic donor chains: domino-paired donation that starts with an altruistic living donor; using compatible pairs and non-simultaneous extended altruistic donor chain [43]. For deceased organ donation, the organs are entered into a pool and are allocated depending on certain criteria such as waiting time length. Currently, gift and altruism rhetoric [44-46] is applied across both living and deceased organ donation in similar ways. This section examines past literature on the role of gift, altruism and reciprocity from a theoretical perspective and from a lay viewpoint to understand cultural norms.

\subsection{Altruism}

Through the lens of altruism, the motivation to donate organs is to increase the welfare of the individual who requires the organ. This concept will be explored through the eyes of the deceased donor families, living donor, the living donor recipient and the general public. 
Deceased donor relatives were motivated to give their consent for their relatives' organs to be donated based on the will of the deceased, attitudes of family members of organ donation, dealing with the situation when the relative died had hopes of the future [48], the view that the organ is a 'gift' and as a sacrifice as families are 'letting go' of their relative [49] as opposed to altruism. Deciding to donate relatives' organs occurs at a time of bereavement and shock and these studies highlight altruism is a less significant part of the decision-making process when compared to living donation.

Deciding to be a living donor is motivated altruism from non-directed living donors' perspectives [50, 51]. Tong et al. [51] found donors were motivated by offering a chance of life driven by a sense of urgency justified by perceived minimal risk, preserving anonymity and gaining benefits from the process such as improved fitness and health. Offering the chance to save a life and wanting to help someone are altruistic, this is agreed among living donors but as Tong et al. found, the benefits are weighed up by the costs of the risks to health and of one's identity being revealed. This shows the altruistic choice is not completely selfless but mediated by the risks and costs to the individual as the economic perspective of altruism purports.

The living organ donation programme itself could impact upon donor and recipient experiences and ideas of altruism and reciprocity. Patel et al. [50] in the UK argued in pooled donation, the altruistic living donor begins the process and could be helping their relative indirectly but the donor may feel coerced and put additional psychological pressure on the donor. In non-directed altruistic donation, Patel et al. elude to the living donor making a significant sacrifice to their psychological health if part of a pooled programme as 
they are not directly benefiting their relative, which has been found to have positive effects on the donor-recipient relationship in most cases [53].

In international attitudinal studies among general populations and Black, Asian and Minority Ethnic (BAME) communities across Europe and the USA, willingness to donate had been the main aim of the studies and the notions of the gift, altruism and reciprocity in general were not directly discussed [i.e. 54-56] but these concepts had arisen in the findings of some studies. Donors were perceived to be altruistic by Hyde and White [57], Sanner [58] and Basu et al. [59] as having knowledge about organ donation influenced altruism [60] although compensation was supported [60]. Exley et al. [61] outlined Sikhism was felt to support giving and helping those in need and organ donation could be viewed as an expression of altruism. Morgan et al. [62] found if there are higher levels of trust in the NHS, people would be more likely to be altruistic. In Sweden, Sanner [63] purported there were different attitude patterns toward organ donation of giving and receiving such as the willingness to receive and give and the willingness to neither to receive nor to give.

These studies show that the message about organ donation policy is framed in altruism and solidarity across Europe, Australia and the UK and is reflected in the participants' responses. When comparing cultural views toward organ donation between USA, Japan and Mexico, Lock and Crowley-Makota found Japan did not accept brain death as a form of death, the cultural view of death as a 'process' than an 'event' and a concern toward the removal of body parts from the dead to be given to non-relatives. Therefore, deceased organ donation is not viewed as a form of altruism, but perhaps a form of 'sacrifice' [64]. Altruism in Japan in the context of organ donation is viewed as reciprocal altruism or devotion and the gift 
would not be a suitable term as gift giving is part of their reciprocal social practices [63] and reflects Gouldner's view of the cultural norms toward reciprocation.

These studies illustrate that altruism is a significant part of the motivation behind organ donation but is a socially and culturally bound concept. Its application in organ donation is universal across all forms of organ donation: being a relative donating a deceased relative's organs to signing the organ donor register posthumously to being a living organ donor for a relative. In this regard, altruism in organ donation solely focuses on the intention of the donor, but disregards the impact of the donated organ on the recipient. The next section examines Mauss's gift exchange in the context of organ donation to explore both recipient and donor perceptions.

\subsection{The Organ as a Maussian Gift}

Mauss's gift exchange theory has been used as a framework to analyse living and deceased organ donation and is praised for encapsulating the ethos of giving in transplantation [66, 53] but criticised for being too simplistic [67].

The obligation to give in deceased organ donation is framed within altruism and gift giving but the concepts of accepting and reciprocating in living organ donation are not so clearly framed [68]. De Groot et al. [68] found recipients had refused to accept a living donor due to concern for the donor's health (75\%), a fear for a negative effect on their relationship among deceased donors (75\%) and $27 \%$ among living donors. Living donors accepted the kidney as they wanted to improve their own quality of life (47\%) and living donors themselves decided to donate their organ to give the recipient autonomy (25\%). The benefit of Mauss's gift exchange theory as it takes into account the recipient's view toward the 
obligation to receive and reciprocate as this mediates whether the ' $g$ ift' is accepted and which form of organ donation is preferred due to the reciprocation implications.

Gill and Lowe [53] analysed living donor and recipient experiences within Mauss's paradigm in the UK. The participants in the study were undergoing living donation or were recipients of an organ from a living donor. For the recipient, it was difficult to accept the organ as it would reduce the donor's wellbeing. By accepting an organ they reported it to be lifechanging but could justify taking the organ once convinced by the donor it was a voluntary choice but they only felt comfortable if certain relatives donated. For the living donors, deciding to donate was relatively simple as it was given in the spirit of generosity and they gained personal satisfaction from the process. Living donation involves a post-transplant relationship, which was the same as pre-donation or had been improved. The emotional impact of the transplant made it challenging for the recipient to thank the donor fully for what they had done for them. The donors felt they had no regrets and improving the life of their relative confirmed why they wanted to be a living donor. For the recipients, they experienced psychosocial problems such as guilt as reciprocation was seen as unrequiteable. They perceived there to be no meaningful form of reciprocation but wanted to show gratitude as there was the concern the donor could feel used.

Gill and Lowes show the difficulty for the recipient to accept the organ when it is directly donated by a relative; the feeling of indebtedness and the impact on their personal relationship. Gerrand [68] purported Mauss's gift exchange theory could be more applicable to living organ donation, in this case direct living donation, than deceased organ donation. As Gill and Lowe highlighted, the 'gift' is given personally and directly as opposed to the organ entering into a pool, like alternative living organ donation programmes and deceased 
organ donation, where the 'gift' is given anonymously and impersonally and has different implications for the recipient who cannot directly thank or reciprocate to their donor.

Shaw $[70,71]$ investigated differences between the conceptualisation of the gift discourse between lay people and health care professionals (HCP) in Australia. Shaw concluded HCPs may presume on behalf of their patients that the concept of the 'gift' may not be appropriate due to Maussian connotations. Lay people and HCPs agreed the term 'gift' in the context of organ donation is seen as altruistic and unilateral without the obligation to reciprocate. Therefore, having a clearer definition of the concept of the organ as a 'gift' or 'altruism' could impact on how organ donation is framed in discussions with potential donor families.

Reciprocity is a key part of Mauss's gift exchange theory and will be discussed in the next section.

\subsection{Reciprocity}

The role of reciprocity to increase organ donation is debated due to the current low uptake of organ donation and the problem of organ trafficking. There have been a range of reciprocity proposals offered: financial rewards for organs to legalise the black market [7278]; contribution to funeral expenses [47, 79]; priority system for registered organ donors who may require an organ, known as a Club model [80]; tax breaks [81] and preferred allocation of organs [82]. These proposals are not all hypothetical as Iran provide financial rewards for living kidney donors, Israel practice the priority system, tax incentives are given in the state of Louisiana, USA and China are piloting a policy of 'help' given through social welfare or a 'thank you' is given in the form of gratitude from the Red Cross Society of 
China. However, reciprocity and financial incentives in organ donation have been condemned for not adhering to bioethical principles [72] although some models have increased organ donation, such as the Israeli priority system where those on the register for more than 3 years and whose family members have become a donor, are prioritised for a transplant [83].

Schweda and Schicktanz [84] examined public ideas toward commercialisation of organ donation in Cyprus, Germany, the Netherlands and Sweden. It was viewed as acceptable to offer incentives for deceased organ donation but not for living donation based on the loss of utility of the organs and the separation of the body and the self upon death. Donation was seen as entering an exchange relationship, with the obligation of reciprocity and a feeling of indebtedness to the donor in itself may be a barrier to accepting the organ. This feeling of indebtedness was believed to be overcome by 'repaying' in some form, perhaps helping in a public campaign or participating in a self-help group. In paired living donation exchange, reciprocity was acceptable based on a give-and-take rationale, based on the Maussian model and could help reduce the feeling of indebtedness the recipient felt. When discussing suitable forms of financial compensation, it was implicit organs have a monetary value although market-based models are not viewed as acceptable as profiting from donation could lead to exploitation. This is echoed in the literature review by Hoeyer et al. [85] who found there is a lower level of acceptance of payment for living donation and a general acceptance of forms of reciprocity such as removing disincentives.

Schweda et al. [86] conducted four focus groups with recipients of deceased organ donation, recipients of living donation, living organ donors and lay people in Germany. Among deceased organ donation recipients, anonymity was problematic as one wanted to 
reciprocate. The authors suggest the Club model, an anonymous element in deceased organ donation to be reconsidered and for psychological counselling for living organ donors and recipients and deceased organ donors to deal with feelings of indebtedness.

In a recent study in the UK among Polish migrants, Sharp and Randhawa [87] explored the concepts of Mauss's gift exchange, reciprocity and altruism. It was found: reciprocity was not expected for donating an organ; donation was motivated by altruistic intentions; the term 'gift' differed in its application in everyday life; the donor family may not accept financial reward for their relative's organs and the donor family could accept funeral expenses for their relative's organs. The acceptance of funeral expenses has been supported as opposed to financial reward in studies $[45,87-91]$. It has been argued there is a shift in public discourse towards reciprocity in organ donation Hayden [92], which may explain why there is a general acceptance of funeral expenses as a form of reciprocation.

Forms of reciprocity have been viewed as acceptable in principle as opposed to financial reward in European countries and in practice in Israel. In Iran, kidneys are remunerated but this market-based system is contested, although Cherry [93] and Matas [94] believes it could be ethically justified. Cherry argued the medical field are not morally above commercial practice and viewing the organ as a gift or altruistic act could in itself coerce organ donation. Discussion will now turn to cultural perceptions toward altruism, gift and reciprocity in organ donation and the challenges of the use of these concepts.

\section{Discussion: Cultural Perceptions and Challenges of the Concepts}

The aim of the article was to discuss cultural perceptions and challenges of altruism, reciprocity and gift theory in living and deceased organ donation. There is little literature 
regarding lay views toward altruism, reciprocity and gift theory in organ donation. The literature has explored this across Europe, the USA, Australia and New Zealand has shown altruism in living and deceased organ donation is a cultural norm that helps others in need but there are differences between the conceptualisation of the 'gift' between the public and HCPs and its use in living and deceased organ donation.

The notion of altruism is problematic as it is applied to all forms of donation and is poorly defined in policy [44-46]. The motivation to donate diverges from helping another in need, could be classed as a self-interested act. Therefore, organ donation through the lens of altruism is narrow and may contribute toward the difficulty in engaging the public as deciding to donate organs is a complex choice.

Recently, the willingness to register as a donor has been found in past studies to be influenced by the belief that giving an organ can save lives but the decision to donate is significantly influenced by social and cultural norms of the rights of the deceased through concerns about body dignity and body totality, a fear of poorer medical attention for registered organ donors and the acceptance of organ donation itself from family members mediated by levels of knowledge $[95,96]$. Therefore, the belief organ donation is a positive act that saves lives is salient but is a decision influenced by myths and deeply rooted cultural practices and beliefs about the body and the treatment of the body after death.

Although the organ was viewed as a 'gift' by deceased donor relatives [48], the applicability of Mauss's gift exchange theory could be limited to deceased donor and pooled living donation programmes as it is anonymous, a one-time event and there are multiple exchanges between the donor family and the recipient. Other gift theories could offer deeper insights into elements of the gift relationship in deceased organ donation such as 
Gregory, Weiner, Deguchi and Godelier who all highlighted the notion of inalienability in gift relationships and this may explain why some donors would prefer to select their recipient as Randhawa [97] found.

Gift exchange theory applied to directed living organ donation explores the obligation to give by the donor as their relative is in need of their organ and for the recipient: the challenge of choosing the donor in that they may prefer to accept a deceased donor instead of a living donor that is not a relative; accepting the organ; changes in the personal relationship between the donor and recipient and the struggles the recipient has in repaying the recipient. Mauss's gift exchange theory cannot be applied to all forms of living donation as there are paired and pooled programmes and non-directed altruistic donation to a stranger where donation could be anonymous, similar to deceased organ donation. Where donation is anonymous, reciprocity may be justified as the donor and donor family could be repaid for their act of generosity as some forms of living donation directly benefit the donor as their relationship may improve and the donor and recipient can return to 'normal' life together. Hayden [92] and gift theorists Cheal $[98,99]$ and Hyde [100] believed gift economies are set within in capitalist society and may explain why reciprocity such as funeral expenses is acceptable in the Western world.

For living donation, it may be better understood through indirect and direct exchanges and where the flow of reciprocity is directed. For example, for indirect exchanges, the recipient may 'pay-back' in a general sense to society but for direct exchanges, the recipient is able to reciprocate to their relative, however the 'tyranny of the gift' [101] is present across all forms of donation as a like-for-life gift cannot be returned. 
From a social exchange perspective, the organs themselves could be items in an exchange between the donor family and the recipient, meaning arguments for reciprocity stand as there is the expectation for reciprocation from Maussian and an exchange viewpoint. For policy makers, using a reciprocity-based strategy to engage the public may be a risk as the framework of the gift and altruism is coming away from the ethos of giving and the bioethical principles that Ross argued to underpin organ donation [72]. Donor families may then feel they are entering into an exchange where the organ begins to hold different 'value' that are conceptualised in a different way, perhaps becoming less inalienable and more alienable, like a commodity and in turn it could influence the motivation to donate. However, having a reciprocal aspect is dealt with by the health care organisation could alleviate guilt or the 'burden' [101] felt by the recipient as he or she may feel the donor family received something in return for 'sacrificing' [102] the organs of their relative at a difficult time. The challenge here is defining an acceptable form of reciprocity in countries where organ donation policy and ethics are deeply rooted in altruism, such as the USA, Australia and the UK.

There are key debates to be had when framing organ donation in policy and society as the definition of altruism and gift needs to be clearer as better definitions could have implications for future strategies, for example whether reciprocity is acceptable, such as a Club model or funeral expenses or whether it is empathy that needs to be fostered through more education and better organisation to remove non-incentives to donate. Alternatively, viewing the organ as a gift in an exchange, reciprocity is justified as it is expected. Without reciprocity, social exchange theory purports the exchange is perpetuated and has 
implications for society, this is discussed further from a social capital perspective in Sharp and Randhawa [103].

Perhaps the key aspect in the conceptualisation of altruism, reciprocity and gift-giving in deceased organ donation by lay people is the motivation behind donating and considering the role that cultural views toward death and the body have. From an altruistic perspective, donating for purely altruistic reasons is idealistic. From a gift and social exchange theory viewpoint, donating organs may be motivated by what is gained such as funeral expenses, perhaps both approaches are viable where deceased organ donation is altruistic and living donation is reciprocated [104], where there are incentives and reciprocity, if regulated properly as Matas et al. [105] argued, incentives and reciprocity could be ethically sound.

\section{Conclusion}

Overall, the concept of altruism is problematic in its definition and application in organ donation. The application of the notion of the 'gift' is poorly defined but Mauss's gift exchange theory enables scholars to explore recipient perspectives as the recipient's role comprises most of the gift exchange cycle.

The obligation to reciprocate has been widely debated in the field of organ donation with little consensus of what is acceptable, further complicated by the fast changing pace of organ transplantation, the number of ways to be an organ donor and cultural perceptions toward the body and death. Until these are clearly defined at a policy level, it is challenging to engage the public in debate about the concepts of altruism, the gift and reciprocity in living and deceased organ donation. At present there is a general consensus across Europe, the USA, Australia and New Zealand that altruism and the ethos of giving a gift is 
synonymous with donation, that reciprocity is accepted but its form is debatable. Perhaps the public is conforming to the cultural norms of donating for altruistic reasons but there are a number of factors in the decision to become a donor and the form of donation that is chosen. There are little myths and misconceptions toward altruism as it is a behaviour practiced in everyday life and is a simple frame to consider organ donation through. The theoretical debates and understandings of altruism, gift and reciprocity have been and are debated widely but coming away from the ethos of giving without reciprocity is not a notion policy makers are comfortable with, in spite of literature supporting this. 


\section{References}

[1] Comte, IA. System of positive policy (Vol. 1). London: Longmans: Green (Original work published 1851); 1875

[2] Kolm, SC, Ythier, JM. Editors. Handbook on the economics of giving, reciprocity and altruism. Amsterdam: Elsevier; 2006

[3] Hann, S. The gift and reciprocity: Perspectives from economic anthropology. In: Kolm, S, Ythier, JM, editors. Handbook on the economics of giving, reciprocity and altruism. Amsterdam: Elsevier; 2006

[4] Camerer, C. Gifts as economic signals and social symbols. A J Soc 1988; 94: S180-94

[5] Farsides, T. Be careful what you with for: What sort of altruism do we want more of in the world? BPS Presentation. London; 2009

[6] Batson, CD. The Altruism Question: Toward a Social-Psychological Answer. Hillsdale, NJ: Arlbaum; 1991

[7] Pinker, S. How the mind works. New York: W.W. Norton and Co.; 1997

[8] Trivers, R. The evolution of reciprocal altruism. QRB. 1971; 46: 35-57

[9] Novak, MA. Evolutionary Dynamics: Exploring the Equations of Life. Belknap Press; 2006

[10] Dawkins, R. The Selfish Gene. New York City: Oxford University Press; 2006

[11] Eisenberg, N. The development of reasoning regarding prosocial behaviour. In Eisenberg, N. editor. The development of prosocial behaviour. New York: Academic Press; 
[12] Eisenberg, N. Altruistic cognition, emotion and behaviour. Hillsdale, NJ: Erlbaum; 1986

[13] Frow, J. Information as gift and commodity. New Left Rev 1996; 219: 89-108

[14] Simmons, RG. Altruism and Sociology. Soc Quarterly 1991; 32: 1-22

[15] Etzioni, A. The moral dimension: Toward a new economics. New York: Free Press; 1998

[16] Darley, JM, Latane, B. Bystander intervention in emergencies: Diffusion of responsibility. J P Soc Psy 1968; 8: 377-83

[17] Piliavin, JA, Dovidio, JF, Gaertner, S, Clark, RD III. Emergency intervention. New York: Academic Press; 1981

[18] Cialdini, RB, Kenrick, DT, Baumann, DJ. Effects of mood on prosocial behaviour in children and adults. In Eisenberg, $\mathrm{N}$ editor. The Development of Prosocial Behaviour. New York: Academic Press; 1982

[19] Hornstein, H.A. Promotive tension: Theory and Research. In. Derlega, V, Grzelak, J editors. Cooperation and helping behavior: Theories and research New York: Academic Press; 1982: p.229-48

[20] Rand, A. The virtue of selfishness: A new concept of egoism. New York: New American Library; 1964

[21] Nietzsche, F. Ecce Homo: The basic writings of Nietzsche translated W. Kaufmann, Modern Library; 1888

[22] Blau, PM. Exchange and power in social life. New York: Wiley; 1964 
[23] Emerson, RM. Toward a theory of value in social exchange. In Cook, KS editor. Social exchange theory. Newbury Park, CA: Sage; 1987

[24] Friedman, D. Notes on 'Toward a theory of value in social exchange'. In Cook, KS editor. Social exchange theory. Newbury Park, CA: Sage; 1987

[25] Levi-Strauss, C. The principle of reciprocity. In Komter, A editor. The gift: an interdisciplinary perspective, Amsterdam: Amsterdam University Press; 1965

[26] Simmel, G. The Philosophy of Money. London: Routledge; 1978

[27] Hobhouse, LT. Morals in evolution: A study of comparative ethics (First edition). London: Chapman \& Hall; 1906

[28] Thurnwald, T. The psychology of acculturation, Am Anthropol 1932; 34: 557-69

[29] Simmel, G. Faithfulness and Gratitude. In: Wolff, K editor. The sociology of Georg Simmel. New York: Free Press; 1950

[30] Malinowski, B. Argonauts of the Western Pacific. London: Routledge; 1922

[31] Goulder, AW. The Norm of Reciprocity: A Preliminary Statement, Am Soc Rev 1960; 25

(2): 171

[32] Sahlins, MD. Stone Age economics. London: Routledge; 1978

[33] Molm, LD, Collett, JL, Schaefer, DR. Building Solidarity through Generalised Exchange: A Theory of Reciprocity, Am J Soc 2007; 113 (1): 205-42

[34] Takahashi, N. The emergence of generalised exchange, Am J Soc, 2000; 10 (4): 1105-34 
[35] Mauss, M. The Gift: Forms and Functions of Exchange in Archaic Societies. London:

Cohen and West; 1954

[36] Gregory, C.A. Gifts and Commodities. London and New York: Academic; 1982

[37] Weiner, AB. Inalienable Possessions: The Paradox of Keeping-While-Giving. Berkeley: University of California Press; 1992

[38] Deguchi, A. Organ transplantation, anthropological gift theories and the self who turns into the other to oneself, Japan J Ethnology 2002; 66 (4): 439-59

[39] Godelier, M. The Enigma of the gift. Cambridge: Polity Press; 1999

[40] Hyde, L. The Gift: Imagination and the Erotic Life of Property. New York: Random; 1983

[41] Bourdieu, P. Language and Symbolic Power. Harvard University Press; 1991

[42] NHS Blood and Transplant. Activity report 2012-2013, 2013;

http://www.organdonation.nhs.uk/statistics/transplant activity report/ [last accessed 28

October 2013]

[43] Wallis, CB, Samy, KP, Roth, AE, Rees, MA. Kidney paired donation, Neph Dial Transplant 2011; 26: 2091-2099

[44] Department of Health. Working together to save lives.

https://www.gov.uk/government/publications/working-together-to-save-lives [last accessed 29 May 2013]; 2011

[45] Nuffield Council on Bioethics. Human Bodies: Donation for Medicine and Research. London: Nuffield Council of Bioethics; 2011 
[46] NHS Blood and Transplant. Strategic Plan 2013-2018,

http://www.nhsbt.nhs.uk/strategicplan/; 2013

[47] Fortin, M-C, Dion-Labrie, M, Hebert, M-J, Doucet, $\mathrm{H}$. The enigmatic nature of altruism in organ transplantation: a cross-cultural study of transplant physicians' views on altruism, BMC Res Notes 2010; 3: 216

[48] Walker, W, Broderick, A, Sque, M. Factors influencing families' decisions about organ donation: An integrative literature review, West J Nurse Res 2013; 35: 1339

[49] Sque, M, Payne, S, Macleod Clark, J. Organ Donation: Gift of life or sacrifice? Mortality, 2006; 11 (2): 117-32

[50] Massey, EK, Kranenburg, LW, Zuidema, WE, Hak, G, Erdman, RAM, Hilhorst, M, Ijzermans, JNM, Busschbach, JJ, Weimar, W. Encouraging psychological outcomes after altruistic donation to a stranger, Am J Transplant 2010; 10: 1445-1452

[51] Tong, A, Craig, JC, Wong, G, Morton, J, Armstrong, S, Schollum, J, Cross, N. "It was just an unconditional gift" Self reflections of non-directed living kidney donors, Clin Transplant 2012; 26: 389-399

[52] Patel, SR, Chadha, P, Paplois, V. Expanding the live kidney donor pool: Ethical considerations regarding altruistic donors, paired and pooled programs, Experiment Clinical Transplant 2011; 3: 181-186

[53] Gill, P, Lowes, L. Gift exchange and organ donation: donor and recipient experiences of live related kidney transplantation. Int J Nurs Stud 2008; 45: 1607- 17 
[54] Schutte, L, Kappel, D.Barriers to donation in minority, low-income and rural populations. Transplant Proc 1997; 29: 3746-7

[55] Ahmed, W, Harris, S, Brown, E. Attitudes to organ donation among South Asians in an English high street. J Roc Soc Med 1999; 92 (12): 626-7

[56] Blok, GA. Approaching donor families: culture, religion and ethnicity. Curr Opin Organ Transplant 2006; 11 (2): 123-9

[57] Hyde, MK, White, KM. Communication prompts donation: exploring the beliefs underlying registration and discussion of the organ donation decision. Brit J Health Psychol $2009 ; 14(3): 423-35$

[58] Sanner, MA. People's attitudes and reactions to organ donation, Mortality 2006; 11 (2): $133-50$

[60] Basu, PK, Hazariwala, KM, Chipman, ML. Public attitudes toward donation of body parts, particularly the eye. C J Ophthalmology 1989; 24 (5): 216-20

[61] Bennet, R, Savani, S. Factors Influencing the Willingness to Donate Body Parts for Transplantation. J Health Soc Policy 2004; 18 (3): 61-87

[62] Exley, C, Sim, J, Reid, N, Jackson, S, West, N. Attitudes and beliefs within the Sikh community regarding organ donation: a pilot study. Soc Sci Med 1996; 43 (1): 23-8

[63] Morgan, SE, Miller, JK. Beyond the donor card: the effect of knowledge, attitudes and willingness to communicate about organ donation to family members. Health Comm 2001; $14(1): 121-34$ 
[64] Sanner, MA. Exchanging Spare Parts or Becoming a New Person? People's attitudes toward receiving and donating organs. Soc Sci Med 2001; 52: 1491-9

[65] Lock, M, Crowley-Makota, M. Situating the practice of organ donation in familial, cultural, and political context. Transplant Rev 2008; 154-7

[66] Wu, AMS, Tang, CS, Yogo, M. Death anxiety, altruism, self-efficacy, and organ donation intention among Japanese college students: A moderated mediation analysis, Aus J Psych 2013; 65: 115-123

[67] Siminoff, L, Chillag, K. The Fallacy of the 'Gift of Life'. Hastings Cent Rep 1999; 29 (6): 3441

[68] de Groot, IB, Schipper, K, van Dijk, S, van der Boog, PJM, Stiggelbout, AM, Baranski, AG, Marang-van de Mheen, P. Decision making around living and deceased donor kidney transplantation: A qualitative study exploring the importance of expected relationship changes, BMC Neph 2012; 13: 103

[69] Gerrand, N. The notion of gift giving and organ donation, Bioethics 1994; 8 (2): 127-150 [70] Shaw, R. The notion of the gift in the donation of body tissues. Soc Research online 2008: $13(6)$

[71] Shaw, R. Perceptions of the gift relationship in organ and tissue donation: Views of intensivists and donor and recipient coordinators. Soc Sci Med 2010; 70: 609-15 [72] Hippen, B, Ross, LF, Sade, RM. Saving lives is more important than abstract moral concerns: financial incentives should be used to increase organ donation. Ann Thor Surg 2009; 88: 1053-63 
[73] Harris, J, Erin, C. An ethically defensible market in organs. BMJ 2002; 325: 114-5

[74] Radcliffe-Richards, J, Daar, AS, Guttman, RD et al, for the International Forum for Transplant Ethics. The case for allowing kidney sales. Lancet 1998; 351: 1950-2

[75] Rabbitt Roff, S. We should consider paying kidney donors. BMJ 2011; 343: 321

[76] van Dijk, G, Hilhorst, M. Financial incentives for organ donation: Investigation of the ethical issues (Ethics and Health Monitoring Report 2007/3) The Hague: Centre for Ethics and Health; 2007

[77] Becker, G, Elias, J. Introducing incentives in the market for live and cadaveric organ donations. J Econ Perspect 2007; 21: 3-24

[78] Arnold, R, Bartlett, S, Bernat, J, et al. Financial incentives for cadaveric organ donation an ethical reappraisal. Transplant 2002; 73: 1361-7

[79] Delmonico, F, Arnold, R, Scheper-Hughes, $\mathrm{N}$ et al. Ethical incentives- not payment - for organ donation. N Eng J Med 2002; 346: 2002-5

[80] Nadel, MS, Nadel, C. Using reciprocity to motivate organ donations. Yale J Health Pol I ethics 2005; 5 (1)

[81] Wellington, AJ, Sayre, EA. An evaluation of financial incentive policies for organ donations in the United States. Contemp econ policy 2011; 29: 1-13

[82] Trotter, G. Preferred allocation for registered organ donors. Transplant Rev 2008: 15862 
[83] Lavee, J., Ashkenazi, T., Stoler, A., Cohen, J., Beyar, R. Preliminary marked increase in the national organ donation rate in Israel following implementation of a new organ transplantation law. Am J Transplant 2013; 13: 780-785

[84] Schweda, M, Schicktanz, S. Public ideas and values concerning the commercialisation of organ donation in four European countries, Soc Sci Med 2008; 68: 1129-1136

[85] Hoeyer, K, Schicktanz, S, Deleuran, I. Public attitudes to financial incentive models for organ donors: a literature review suggests that it is time to shift the focus from 'financial incentives' to 'reciprocity', Transplant Int 2013; 26: 350-357

[86] Schweda, M, Wohlke, S, Schicktanz, S. Understanding public scepticism toward organ donation and its commercialisation: The important role of reciprocity, Transplant Proc 2009; 41: $2509-2511$

[87] Sharp, C, Randhawa, G. Organ donation as an 'altruistic gift': Incentives and reciprocity in deceased organ donation from a UK Polish migrant perspective. Ann Transplant 2014; 19: 23-31

[88] Kittur, DS, Hogan, MM, Thukral, VK, McGaw, LJ, Alexander, JW. Incentives for organ donation? Lancet 1991; 338: 1441-3

[89] DeJong, W, Drachman, J, Gortmaker, SL, et al. Options for increasing organ donation: the potential role of financial incentives, standardised hospital procedures and public education to promote family discussion. Millbank Quarterly 1995; 73 (3): 463-79 [90] McFarland, JG, Aster, RH, Buggy, BP. Paid time off for blood donation - an incentive to be less than truthful? Transfusion 1997; 37: 447-48 
[91] Nickerson, CAE, Jasper, JD, Asch, DA. Comfort level, financial incentives and consent for organ donation. Transplant Proc 1998; 30: 155-9

[92] Hayden, C. Taking as giving: Bioscience, ethics and the politics of benefit-sharing. Soc Stud Sci 2007; 37 (5): 729-58

[93] Cherry, MJ. Why should we compensate organ donors when we can continue to take organs for free? A response to some of my critics, J Med Phil 2009; 34: 649-673

[94] Matas, AJ. Why we should develop a regulated system of kidney sales: A call for action! Clinical J Am Soc Neph 2008; 1 (6): 1129-1132, http://cjasn.asnjournals.org/content/1/6/1129.full [95] Irving, MJ, Tong, A, Jan, S, Cass, A, Chadban, S, Allen, RD, et al. Community attitudes to deceased organ donation: A focus group study. Transplant 2012; 93 (10): 1064-9

[96] Morgan, M, Kenten, C, Deedat, S, On Behalf of the DonaTE Programme Team. Attitudes to deceased organ donation and registration as a donor among minority ethnic groups in North America and the UK: A synthesis of quantitative and qualitative research. Ethnicity Health 2013; 18 (4)

[97] Randhawa, G. An exploratory study examining the influence of religion on attitudes towards organ donation among the Asian population in Luton, UK. Neph, dial, transplant 1998; 13 (8): 1949-54

[98] Cheal, D. The social dimensions of gift behaviour. J Soc Pers Relat 1986; 3 (4): 423-39

[99] Cheal, D. The Gift Economy. London and New York: Routledge; 1988 
[100] Hyde, L. The Gift: Imagination and the Erotic Life of Property. New York: Random; 1983

[101] Fox, RC, Swazey, JP. The courage to fail: A social view of organ transplants and dialysis. New Edition. Transaction Publishers: New Brunswick; 2002

[102] Sque, M, Payne, S, Macleod Clark, J. Gift of life or sacrifice? Key discourses for understanding decision-making by families of organ donors. In: Sque, M, Payne, S. editors. Organ and tissue donation: an evidence base for practice. Berkshire, UK: Open University press; 2007

[103] Sharp, C, Randhawa, G. Social capital and deceased organ donation. In: Randhawa, G. editor. Organ donation and transplantation: Public policy and clinical perspectives. InTech: Open Access; 2012

[104] Goodwin, M. Black Markets: The supply and demand of body parts. Cambridge University Press: Cambridge; 2006

[105] Matas, AJ et al. Incentives for organ donation: Proposed standards for an internationally acceptable system, Am J Transplant 2012; 12:306-12 